\title{
PENGARUH PENYULUHAN METODE CERAMAH DALAM MENINGKATKAN PENGETAHUAN MASYARAKAT TERHADAP PENYAKIT TUBERKULOSIS
}

\author{
Safari Wahyu Jatmiko, Fitka Romanda, Muhammad Alim Abdulmajid Hidayatulloh \\ Fakultas Kedokteran Universitas Muhammadiyah Surakarta \\ safari.wahyu@ums.ac.id
}

\begin{abstract}
Background: Number of patients with tuberculosis (TB) in the region of Surakarta ranked 10th largest in the Central Java, although the government has already implemented the DOTS strategy. One factor contributing to the high number of TB patients is the lack of public knowledge of TB. The population of the city of Surakarta is 552.650 inhabitants and 12.480 of them live in Kalurahan Jagalan. Of the 12,480 people, nearly 60 percent of them have junior high school education and below. This requires education about TB to improve people's understanding of TB with the right method. Objective: to determine the effect of counseling using the lecture method in increasing public knowledge of TB disease in the Sunday Morning Prayer of Jagalan Baiturrohman Mosque. Method: This study used one group pretest and posttest pre-experimental research design involving 84 research subjects. Counseling was conducted with lecture methods on research subjects. Pretest and posttest were conducted to determine the effectiveness of the lecture method counseling. Results: The results showed that the average value of pre-test was 5.48 (1.2) while the average value of the post-test was 7.42 (0.9). The results of the analysis using Wilcoxon statistical test found that there was a significant difference between the mean of the pre-test value with the mean post-test value $(p=0,000)$. Conclusion: counseling with varied lecture methods is an effective method to increase public knowledge about tuberculosis.
\end{abstract}

Keywords: Education, counseling, lecturing, level of education, Tuberculosis

\begin{abstract}
Abstraksi. Latar belakang : Jumlah penderita Tuberkulosis (TB) di wilayah surakarta menduduki peringkat ke 10 terbanyak di Jawa Tengah, meskipun pemerintah kota Surakarta sudah menerapkan strategi DOTS. Salah satu faktor penyebab tingginya jumlah penderita TB adalah kurangnya pengetahuan masyarakat terhadap TB. Jumlah penduduk kota Surakarta 552.650 jiwa dan 12.480 diantaranya tinggal di wilayah Kalurahan Jagalan. Dari 12.480 jiwa tersebut, hampir 60 persennya berpendidikan SLTP ke bawah. Hal ini memerlukan edukasi tentang TB untuk meningkatkan pemahaman masyarakat terhadap TB dengan metode yang tepat. Tujuan : untuk mengetahui pengaruh penyuluhan menggunakan metode ceramah dalam meningkatkan pengetahuan masyarakat terhadap penyakit TB pada jamaah Pengajian Ahad Pagi Masjid Baiturrohman Jagalan. Metode : Penelitian ini menggunakan desain penelitian pre experimental one group pretest and posttest dengan melibatkan 84 subyek penelitian. Dilakukan penyuluhan dengan metode ceramah pada subyek penelitian. Pretes dan postes dilakukan untuk mengetahui efektifitas penyuluhan metode ceramah. Hasil : Hasil penelitian menunjukkan bahwa nilai ratarata pre test adalah $5,48(1,2)$ sedangkan nilai rata-rata post tes adalah $7,42(0,9)$. Hasil analisis menggunakan uji statistik Wilcoxon didapatkan terdapat perbedaan bermakna antara rerata nilai pre test dengan rerata nilai post test dengan $p=0,000$. Kesimpulan : penyuluhan dengan metode ceramah bervariasi merupakan metode yang efektif untuk meningkatkan pengetahuan masyarakat mengenai penyakit tuberkulosis.
\end{abstract}

Kata Kunci: Edukasi, penyuluhan, ceramah, tingkat pendidikan, tuberkulosis 


\section{PENDAHULUAN}

Pemerintah Kota Surakarta telah menerapkan strategi DOTs untuk penanggulangan penyakit Tuberkulosa (TB) di seluruh Puskesmas, Rumah Sakit negeri, dan Rumah Sakit swasta (Netra, 2011). Meskipun demikian, jumlah penderita TB di Surakarta masih menduduki peringkat sepuluh besar untuk wilayah Provinsi Jawa Tengah (Palupi, 2013). Diantara penyebab tingginya penderita TB adalah masih rendahnya pengetahuan masyarakat tentang penyakit TB (Utarini et al, 2011).

Wilayah Surakarta terdiri atas lima kecamatan dengan jumlah penduduk sebanyak 552.650 jiwa. Penduduk ini tersebar di 5 kecamatan yaitu Kecamatan Laweyan, Serengan, Pasar Kliwon, Jebres, dan Banjasari (Dispendukcapil Surakarta, 2015). Jumlah penduduk di Kecamatan Jebres adalah 148.442 orang, sedangkan jumlah penduduk di wilayah Kalurahan Jagalan Kecamatan Jebres adalah 12.480 orang (BPS Surakarta, 2014).

Berdasarkan statistik yang dikeluarkan oleh BPS Surakarta menunjukkan bahwa hampir 60\% penduduk kalurahan Jagalan berpendidikan SLTP ke bawah. Hal ini menjadikan masalah tersendiri dalam usaha untuk mengurangi angka penderita tuberkulosis di wilayah kalurahan Jagalan, mengingat faktor pengetahuan terhadap penyakit tuberkulosis sangat mempengaruhi sikap dan perilaku masyarakat dalam usaha memberantas penyakit TB (seperti keikutsertaan dalam imunissi BCG, penemuan kasus baru, keterlibatan dalam suksesnya program DOTS).
Mengingat rendahnya tingkat pendidikan dan pengetahuan ini, maka diperlukan edukasi untuk meningkatkan pengetahuan masyarakat terhadap penyakit tuberkulosis. Berbagai cara dapat diterapkan untuk melakukan edukasi, diantaranya adalah penyuluhan dengan metode ceramah.

Tujuan penelitian ini adalah untuk mengetahui pengaruh penyuluhan menggunakan metode ceramah dalam meningkatkan pengetahuan masyarakat terhadap penyakit TB pada jamaah Pengajian Ahad Pagi Masjid Baiturrohman Jagalan. Manfaat yang bisa diperoleh adalah mendapatkan metode yang efektif, murah, dan mudah untuk meningkatkan pengetahuan masyarakat. Selain itu dengan peningkatan pengetahuan tentang TB pada jamaah pengajian ahad pagi Masjid Baiturrohman Jagalan maka segala hal yang dibutuhkan oleh masyarakat awam tentang penyakit TB dapat terpenuhi, sehingga peningkatan pengetahuan ini diharapkan bisa menurunkan angka penderita TB di Jagalan pada khususnya dan Surakarta pada umumnya.

\section{METODE PENELITIAN}

Penelitian ini menggunakan desain penelitian pre experimental one group pretest and posttest (Kristina, 2016). Populasi target adalah jamaah pengajian ahad pagi Masjid Baiturrohman Jagalan Kecamatan Jebres Surakarta, sedangkan populasi aktual adalah jamaah pengajian ahad pagi Masjid Baiturrohman Jagalan yang hadir pada saat penelitian. Berdasarkan rumus besar sampel analisis dua variabel numerik berpasangan maka 
didapatkan bahwa minimal jumlah sampel adalah 35 orang (Dahlan, 2013).

Realisasi penelitian secara ringkas diuraikan sebagai berikut:

1. Koordinasi tempat pelaksanaan kegiatan dengan pengurus Pengajian Ahad Pagi Masjid Jami Baiturrohman Jagalan Kecamatan Jebres Solo. Disepakati bahwa pelaksanaan penelitian dilakukan pada hari Ahad 14 Februari 2016.

2. Penyusunan materi penyuluhan dengan menggunakan power point satu minggu sebelum pelaksanaan.

3. Pada hari pelaksanaan dilakukan pre test terhadap peserta pengajian.

4. Penilaian pre test oleh mahasiswa.

5. Pelaksanaan ceramah interaktif beserta tanya jawab selama 1 jam.

6. Memberikan soal post tes kepada peserta pengajian.

7. Mahasiswa melakukan penilaian terhadap post tes

8. Pengumpulan dan pengolahan data

9. Analisis statistik terhadap data yang didapat dengan uji beda rerata data berpasangan menggunakan software statistik.

\section{HASIL DAN PEMBAHASAN}

Pada penelitian ini didapatkan 84 orang yang mengikuti penelitian. Hasil penelitian menunjukkan bahwa nilai ratarata pre test adalah 5,48 $(1,2)$ sedangkan nilai rata-rata post tes adalah 7,42 $(0,9)$. Bedasarakan uji normalitas data menggunakan uji kolmogorov-smirnov didapatkan nilai $\mathrm{p}<0,05$ yang menunjukkan bahwa distribusi data tidak normal. Hasil uji distribusi data membuat peneliti menggunakan uji statistik Wilcoxon sebagai alternatif dari uji $t$ berpasangan (Dahlan, 2013).

Hasil analisis menggunakan uji statistik Wilcoxon didapatkan terdapat perbedaan bermakna antara rerata nilai pre test dengan rerata nilai post test dengan $\mathrm{p}$ $=0,000$. Perbedaan nilai pre test dan post test dapat dilihat pada grafik box plot berikut.

Gambar 1. Grafik box plot nilai pre test dan pos test

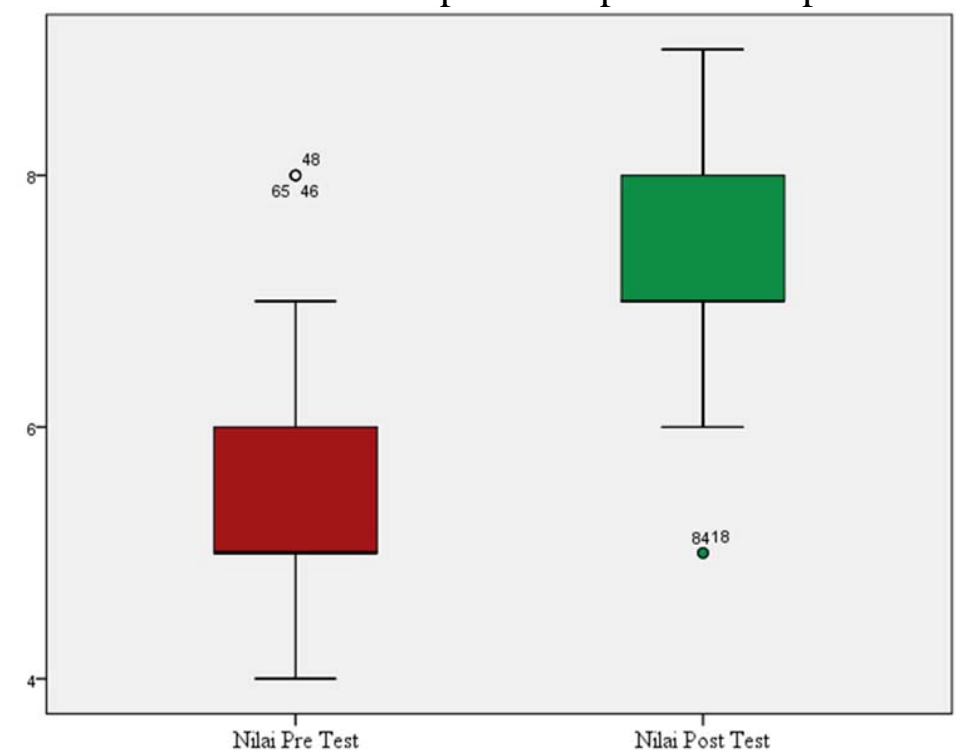


Pada penelitian ini, penulis menggunakan metode ceramah. Menurut Kamus Besar Bahasa Indonesia, ceramah adalah pidato oleh seseorang di hadapan banyak pendengar, mengenai suatu hal, pengetahuan, dan sebagainya (KBBI, 2016). Pemilihan metode ceramah dalam edukasi pada penelitian ini berdasarkan:

1. Metode ceramah merupakan metode yang mudah dilakukan. Tempat pelaksanaan yang berada di Masjid menjadikan metode ceramah menjadi metode yang paling memungkinkan untuk dilaksanakan mengingat fasilitas yang sangat terbatas jika dibandingkan dengan sekolahan.

2. Metode ceramah tidak memerlukan organisasi yang rumit di dalam pelaksanaannya. Hubungan organisatoris yang berbeda dan ketiadaan garis komando antara penceramah dengan penyelenggara kajian membuat metode ceramah menjadi metode yang terbaik dalam melakukan edukasi.

3. Tujuan penelitian adalah sebatas meningkatkan pengetahuan masyarakat terhadap penyakit tuberculosis sehingga tidak membutuhkan metode yang rumit di dalam pelaksanaannya.

4. Penceramah bukan seorang dengan latar belakang sarjana pendidikan sehingga kurang menguasai berbagai macam metode pembelajaran.

5. Peserta ceramah adalah kalangan ibu-ibu yang mempunyai latar belakang pendidikan beragam. (Helmi, 2016).

Pada penelitian ini, penulis membuktikan bahwa metode ceramah efektif dalam meningkatkan pengetahuan masyarakat terhadap penyakit tuberkulosis. Hal ini dibuktikan dengan terjadinya peningkatan nilai post tes jika dibandingkan dengan nilai pre tes setelah dilakukan perlakuan berupa ceramah dengan $\mathrm{p}=0,000$. Efektifitas metode ceramah ini juga dibuktikan oleh penelitian lain seperti penelitian Emiwati (2012) yang membuktikan bahwa ceramah meninggkatkan pengetahuan siswa Madrasah Tsanawiyah.

Selama ini metode ceramah dianggap metode yang kurang baik di dalam proses pembelajaran. Penelitian yang dilakukan oleh Amaliah et al (2014) menunjukkan bahwa metode diskusi lebih baik daripada metode ceramah, demikian juga dengan penelitian yang dilakukan oleh Wijaya (2016) yang menyatakan bahwa metode Student Teams Achievement Division lebih baik daripada metode ceramah. Faktor-faktor yang menyebabkan keberhasilan ceramah kami dalam meningkatkan pengetahuan masyarakat terhadap penyakit tuberkulosis diantaranya adalah:

1. Penggunaan power point, sehingga memudahkan peserta pengajian lebih fokus memperhatikan materi ceramah.

2. Penggunaan video di dalam salah satu slide menjaga peserta untuk tetap fokus pada materi.

3. Lebih banyak menampilkan gambar di dalam power point menjadikan penjelasan ceramah selalu menarik.

4. Memasukkan selingan ringan di sela-sela ceramah yang membantu peserta terhindar dari rasa bosan.

5. Memasukkan Tanya-jawab di selasela ceramah sehingga peserta 
memperhatikan jawaban yang benar dari pertanyaan.

Tata cara ceramah yang seperti ini sering disebut dengan metode ceramah bervariasi (Harsono et al, 2009; Ismail, 2013).

Keterbatasan di dalam penelitian ini antara lain adalah:

1. Keterbatasan waktu yang dimiliki oleh peserta pengajian dan tim peneliti, serta banyaknya kegiatan yang bertempat di Masjid baiturrohman Jagalan, sehingga tidak memungkinkan bagi peneliti untuk melakukan penelitian dengan desain eksperimental murni. Desain eksperimental murni lebih memberikan asosiasi sebab akibat yang lebih baik (Alatas et al, 2014).

2. Kesulitan untuk melakukan follow up pengetahuan subyek penelitian pasca penyuluhan sehingga tidak diketahui berapa lamakah pengetahuan tersebut akan bertahan (retensi). Retensi yang baik menunjukkan bahwa metode yang digunakan adalah tepat (Hikmawati, 2016). Hal ini sebenarnya penting karena peningkatan pengetahuan tidak identik dengan peningkatan retensi pengetahuan (Syamola, 2016).

3. Kesulitan peneliti untuk mengetahui implementasi dari pengetahuan yang telah didapat dalam praktek nyata sehari-hari. Hal ini sebenarnya penting karena ilmu yang merupakan bagian dari pengetahuan tidaklah disebut sebagai ilmu jika tidak merubah perilaku seseorang (Yudha, 2016).

\section{SIMPULAN}

Penelitian ini membuktikan bahwa penyuluhan dengan metode ceramah bervariasi merupakan metode yang efektif untuk meningkatkan pengetahuan masyarakat mengenai penyakit tuberkulosis. Metode ceramah bervariasi merupakan metode yang tepat untuk melakukan penyuluhan di masyarakat dengan latar belakang dan setting tempat seperti kondisi kami.

Berdasarkan keterbatasan yang ada pada penelitian ini maka dapat disarankan bahwa:

1. perlu diadakannya penelitian lagi dengan topik yang sama namun menggunakan desain eksperimental murni.

2. Perlu dilakukan penelitian untuk menilai retensi dan implementasi hasil penyuluhan.

\section{PERSANTUNAN}

Peneliti mengucapkan terima kasih kepada Pimpinan Ranting Pemuda Mumahammadiyah Jagalan sebagai penyelenggara pengajian ahad pagi dan takmir Masjid Baiturrohman Jagalan Kecamatan Jebres Surakarta yang mengijinkan dan mendukung penelitian ini. 


\section{DAFTAR PUSTAKA}

Alatas H., Karyomanggolo WT., Musa DA., Boediarso A., Oesman IN., Idris NS., (2014), Desain Penelitian. dalam : Sastroasmoro S., Ismael S (eds), Dasar-dasar Metodologi Penelitian Klinis. Edisi 5. Jakarta: Sagung Seto. 104-27

Amaliah R R., Fadhil A., Narulita S. (2014). Penerapan Metode Ceramah dan Diskusi Dalam Meningkatkan Hasil Belajar PAI di SMA Negeri 44 Jakarta. Jurnal Studi AlQur'an;10(2):119-31

Badan Pusat Statistik Kota Surakarta., (2014). Luas Wilayah, Jumlah Penduduk, Rasio Jenis Kelamin dan Tingkat Kepadatan Tiap Kecamatan di Kota Surakarta 2014. Available from:http://surakartakota.bps.go.id/linkTabelStatis/view/id/12

Dahlan MS., (2013), Besar Sampel dan Cara Pengambilan Sampel dalam Penelitian Kedokteran dan Kesehatan. Edisi 3. Jakarta: Penerbit Salemba Medika. 72-5

Dahlan MS., (2013), Statistik untukKedokteran dan Kesehatan. Edisi 5. Jakarta: Penerbit Salemba Medika. 31-69

Dispendukcapil Surakarta, (2015), Jumlah dan Persebaran Penduduk, available from: http://dispendukcapil.surakarta.go.id/20XIV/index.php/en/2014-05-21-04-43-

06/2015-03-13-02-12-24/kuantits-penduduk

Emiwati. (2012). Penerapan Metode Ceramah Dalam Memahami Pelajaran Ketenagakerjaan Di Kelas Viii Mts Hasanah Pekanbaru. Pekan Baru: Universitas Islam Negeri Sultan Syarif Kasim Riau. Skripsi

Harsono B., Soesanto., Samsudi. (2009). Perbedaan Hasil Belajar Antara Metode Ceramah Konvensional dengan Ceramah Berbantuan Media Animasi aada Pembelajaran Kompetensi Perakitan dan Pemasangan Sistem Rem. J PTM; 9(2):71-9

Helmi J., (2016) Penerapan Konsep Silberman dalam Metode Ceramah Pada Pembelajaran PAI. Available from: http://download.portalgaruda.org/article.php?article=498433 \&val=10213\&title=PENERAPAN\%20KONSEP\%20SILBERMAN\%20\%20DALA M\%20\%20METODE\%20\%20CERAMAH\%20PADA\%20\%20PEMBELAJARAN $\% 20 \% 20$ PAI.

Hikmawati VY., (2016), Profil Retensi Pengetahuan Siswa SMA pada Materi Sistem Pertahanan Tubuh Melalui Metode Membaca SQ5R. J Bio Edu; 1(1):55-63

Ismail MW., (2013). Peningkatan Hasil Belajar Melalui Metode Ceramah Bervariasi Dengan Model Pembelajaran Berkelompok Tipe Nht (Numbered Head Together) Pada Mata Diklat Stenografi Kelas Xi Bidang Administrasi Perkantoran Smk Nurul Ulum Lebaksiu Kabupaten Tegal. Semarang: Universitas Negeri Semarang. Skripsi

Kamus Besar Bahasa Indonesia. (2016). Ceramah. Available from: https://kbbi.kemdikbud.go.id/entri/ceramah

Kemenkes, (2014), Profil Kesehatan Indonesia, availabe from: http://www.depkes.go.id/resources/download/pusdatin/profil-kesehatanindonesia/data-dan-informasi-2014.pdf 
Kristina TN., (2016), Pedoman Praktis Penulisan Karya Ilmiah Kesehatan \& Penerapan Metodologi Penelitian. Edisi I. Semarang : Universitas Diponegoro. 86-95

Netra AK., (2011), Perlukah Kekuatan Hukum yang Memaksa dalam Program Penanggulangan TB?, CDK; 183:38(2), 141-2

Palupi DLM., (2013). Pengaruh Pendidikan Kesehatan Terhadap Perubahan Pengetahuan,Sikap dan Perilaku Penderita Tuberculosis yang Berobat di Wilayah Kerja Puskesmas Surakarta. Surakarta: UNS. Tesis

Raviglione MC, O’Brien RJ., (2010). Tuberculosis. In: Loscalzo J (eds), Harrison's Pulmonary and Critical Care Medicine. New York:McGraw Hill Medical, 115-138

Syamola D., (2016), Perbedaan Peningkatan Pengetahuan dan Retensi Ingatan Edukasi Kesehatan Mengenai Perilaku Hidup Bersih dan Sehat Antara Buku Interaktif Dan Flip Chart Pada Siswa SD N 29 Dadok Tunggul Hitam Kecamatan Koto Tangah Kota Padang. Padang: Universitas Andalas. Skripsi

Utarini A., Wuryaningtyas B, Basri C, Natpratan C, Harbianto D, Muljono I, Voskens J, et al, (2011), Strategi Nasional Pengendalian TB di Indonesia 2010-2014, Jakarta: Kementerian Kesehatan Republik Indonesia Direktorat Jenderal Pengendalian Penyakit dan Penyehatan Lingkungan, 14

Wijaya DS. (2016). Penerapan Model Student Teams Achievement Division (Stad) Dan Metode Ceramah Terhadap Peningkatan Prestasi Belajar Ips Pada Siswa Kelas V Sd Negeri 1 Rajabasa Raya Bandar Lampung. Bandar Lampung: Universitas Lampung. Skripsi

World Health Organization., (2014), Global tuberculosis report 2014, Geneva:WHO, 1

Yudha R., (2016), Implementasi nilai-nilai keilmuan dalam proses belajar. Available from: http://rikiyudha.web.ugm.ac.id/2016/04/29/implementasi-nilai-nilai-keilmuandalam-proses-belajar/ 